\title{
Blurring the Boundaries between Leisure and Work: Professionals as Devotees in the Mind-Sport Bridge
}

\author{
Zoe Russell $^{1}$ (1) Samantha Punch ${ }^{1} \cdot$ Ian McIntosh $^{1}$
}

Received: 24 November 2020 / Accepted: 26 October 2021 / Published online: 19 November 2021

(C) The Author(s) 2021

\begin{abstract}
Bridge is a partnership card game that has increasingly professionalized in recent years, particularly at 'elite' level. 'Elite' bridge players participate in a unique leisure world which hitherto has been understood as a form of serious leisure. However, due to professionalization there is the possibility to work as a professional bridge player thus blurring the boundaries between leisure and work. The paper is based on the lived experiences of professional bridge players and how they understand the, often ongoing, transition from playing bridge as a hobby to playing bridge for a job. Being a professional bridge player raises issues about moral evaluations of work, a work ethic and concerns over what a 'proper job' is. This paper explores these dynamics in relation to Stebbins concept of 'devotee work' and ideas of liminality, unpacking the tensions and ambiguities involved through the perspective of 52 elite bridge players. Findings from the qualitative interviews illustrate how playing bridge professionally is often experienced as being hugely positive, because of being paid to do something one is devoted to, but ambivalences and anxieties also emerge. In addition, the paper draws on the reflections of one author who is a bridge player and blurs the boundaries between work and leisure through the academic study of bridge. The findings show the contested nature of bridge as a profession set within broader notions of work, with positive and negative perceptions of the blurring of work-leisure boundaries.
\end{abstract}

Keywords Bridge $\cdot$ Devotee work $\cdot$ Leisure $\cdot$ Mind-sport $\cdot$ Profession

Zoe Russell

z.o.russell@stir.ac.uk

Samantha Punch

s.v.punch@stir.ac.uk

1 Faculty of Social Sciences, University of Stirling, Stirling, UK 


\section{Introduction}

Bridge is a trick-taking card game that can be played as a form of leisure and can also provide a means of generating income for players at the top levels. As a serious leisure pursuit, bridge is played by individuals who have committed significant time and effort to this intellectual mind-sport, often having been introduced to the game through family at a young age. Played with two competing pairs, bridge requires players to invest in their own skills development over time and to generate successful outcomes in partnership with others. Players who reach the 'elite' level of bridge participate in a unique leisure world comprising of social interactions at the bridge table in international tournaments, and the wider social settings that comprise 'extended leisure experiences' (Scott \& Harmon, 2016). However, for those at the top level, bridge also has the potential to become work, with opportunities to be paid to play as a professional. In that sense, the elite level of bridge is unique in comprising players who are full-time and part-time professionals, amateurs who are not paid to play, and sponsors who participate as players.

Thus far, elite bridge has been explored as a form of serious leisure (Stebbins, 2017a) as a conceptual lens to analyse themes of strategic interaction, identity and emotion from a sociological perspective, particularly following symbolic interactionist theory (Punch et al., 2020). This paper considers elite bridge through the lens of 'devotee work' (Stebbins, 2017b) and the ideas of blurring the boundaries between work and leisure. The main difference between serious leisure and devotee work is that the latter is so attractive to those that engage in it, that work is essentially leisure and, unlike the former, workers are paid for their efforts (Stebbins, 2004). We explore the complexities involved in the notion of bridge as work, interrogating the concept of 'profession' understood through players' experiences and drawing on literatures from work and leisure studies. Through an analysis of qualitative interviews with elite players, we consider their perceptions of occupational devotion and whether the 'positiveness on the job' (Stebbins, 2020, p.47) is viewed as 'ideal'. We aim to theorize the blurring of the boundaries between work and leisure in a mind-sport and discuss the implications for sociological knowledge more broadly from the notion of bridge as a liminal space of work-leisure.

Veblen (1899) long ago noted an historical distinction between the 'base' and the 'honourable', where dishonour was attached to 'productive employment' given that such labour was strongly associated with 'subjection to a master', thus it was leisure, for Veblen, that was seen to be 'ennobling' in the eyes of civilized peoples' (Strangleman \& Warren, 2008, p.217; see also Roberts, 2013). Decades later Hannah Arendt (1958) offered her famous and influential distinction between 'work' and 'labour'. For Arendt, labour corresponds to the biological process of the human body, part of the life cycle of growth and inevitable decay, whereas work provides a world of things distinct from nature, and as such 'work bestows permanence and durability upon mortal life and fleeting character of human time' (Applebaum, 1992, p.492). These may seem rather grand and portentous debates to draw upon in relation to an exploration of the world of professional bridge. However, understandings of both leisure and work and the relation between them, professional ethics and 
an associated normative outlook, self-identification with occupations, ideas about worth, craft and responsibility and the attachment and development of devotee work, can, we would argue, all be considered and illuminated through a detailed look at the 'lived experience' (McIntosh \& Wright, 2019) of the professional bridge player.

\section{Methodology}

This paper draws from a qualitative sociological research project that aimed to shed light on an understudied social world that blurs the lines between work and leisure, elite tournament bridge. As an elite player herself, Punch was able to draw on her own lived experienced in this social world to conduct insider research with the broader elite playing community (for a more detailed discussion of insider challenges, see Punch \& Rogers, 2021). Insider research occurs across a continuum dependent on the closeness of the researcher to their research subject (Mercer, 2007) and may be exploring new areas of a familiar context or collecting data from close contacts and scrutinizing oneself (Fleming, 2018). This insider position shaped the research design, method of data collection and data analysis (Fleming, 2018) and through combining work and leisure by researching her passion for the mindsport of bridge, Punch has lived experience of the concepts we discuss in this paper. Researching one's leisure activity is a rewarding privilege, but also involves tensions, constraints and contradictions. This experience chimes with Sohn's (2018) discussion of phenomenon, where the need for both patience and persistence as part of the process of trying to merge two professional paths, can be unsettling and require effort to persuade funders and advisors of the merits of this work.

The 'elite' community is defined as players who have reached the top levels of the mind-sport bridge, for example having won regional, national or international championships, and represented their country. At this level, bridge can become a profession and a lifestyle for players, however, the group comprises both professional and amateur players, a unique situation across many sporting and game settings. Elite and professional bridge players are usually experts who are paid to play, either with the sponsor in a partnership or with their regular partner on a sponsored team. Professional players can dedicate their full-time career to bridge or play professionally on a part-time basis or when retired from other employment. Some of the elite players are paid a salary as a retainer in order to make themselves available to one specific sponsor, others play for different sponsors in different events. Professional players can be involved in negotiating their pay in such situations alongside managing client-relationships more broadly. Bridge 'professionals' are not in every case better players than amateurs, although they overwhelmingly are, but regardless there continues to exist a combination of amateur and professional in the same playing environments.

The study was based on in-depth interviews with a purposeful sample of elite players, access to which was possible due to the insider status of Punch. Questions were designed to capture the subjective experiences of top players which are little understood and to explore the social interactions that connect diverse players of this international mind-sport. The sample consisted of male and female players, 
aged 17 to 78, of North American, British and European nationality and comprised 37 professionals, 12 amateurs and 3 sponsors. As part of the study design, players were asked to participate based on being named in the research outputs, to generate insightful data not just for academic purposes, but for bridge organizations to increase awareness of and interest in the game. Players gave consent for this at the time of interview and, for sensitive quotes, players could choose for these to appear as anonymous, otherwise all names used are real player names. ${ }^{1}$

Interviews with players lasted on average two hours, and questions covered a range of topic areas including how they started playing, partnership and team dynamics. For the topic of professional bridge, players were asked what it was like being a paid bridge player, how they became a professional, the advantages and disadvantages of the professionalization of bridge (including what they like/ dislike about it personally) and the qualities they prefer in their bridge employer (the sponsor). Interview transcripts were coded according to a thematic coding framework that corresponded to the interview guide and was designed to generate codes that could be subject to further theoretical and conceptual analysis. For the whole project, 15 themes and 72 codes were produced from all 52 interviews. The findings herein arose from a qualitative thematic analysis (Braun \& Clarke, 2006; Vaismoradi et al., 2016) of a subset of codes, namely those pertaining to the subject of bridge as a profession. Analysis of the subset of codes produced specific thematic findings which are presented herein alongside interpretation that arose through dialogue between authors relating to both relevant theories and concepts and the lived experience of Punch in elite bridge.

Overall the process unfolded across four stages of qualitative thematic analysis from initialisation, construction, rectification to finalization (see Vaismoradi et al., 2016). The approach is fundamentally interpretative and relies on 'researcher's subjectivity and personal insight to interpret data for theme development' (Vaismoradi \& Snelgrove, 2019, n.p). Analysis drew on the benefits of the 'pre-understandings' that an insider researcher has of the subject matter (Brannick \& Coghlan, 2007) where insights might be difficult to generate as an outsider. Additionally, non-bridge playing authors who have not been socialized into the group under study were able to problematise elements of the data relating to bridge that may be taken for granted by a bridge player, even one who is also a sociologist (see also Punch \& Rogers, 2021).

\section{Bridge as Work: 'I don't think it's a proper job'}

For Budd (2011, p.145) 'work is not just a source of economic... utility, it is a source of psychological and social meaning'. Work, then, can be central to one's identity and sense of self; a key way in which one's 'consociates' (Schutz,

\footnotetext{
${ }^{1}$ Consent for the entire project was secured through the Ethics Committee of the Faculty of Social Sciences at the University of Stirling for the research to take place, including reference to the naming of players.
} 
1967) develop an understanding of who you are. Work identities emerge out of an ongoing relation between how we see ourselves and how we think others see us (Goffman, 1990; Hughes, 1971). This emerged in Punch et al.'s (2020) examination of elite bridge leisure identities with a sense that professionals in particular were conscious of their presentations of self as part of impression management associated with different frontstage and backstage bridge identities (Goffman, 1990). To contextualize and build on this, we explore the professionalization of bridge and bridge as a form of devotee work which blurs boundaries between work and leisure. For Stebbins (2017a, p.4) devotee work is a form of serious leisure in which it is possible to derive a livelihood and is based on feeling a 'powerful devotion' to an activity or occupation that one is 'proud to be in'. Devotee work offers those engaged in it a high sense of achievement through 'core activities' which have intense appeal and as such virtually erase the line between work and leisure (ibid).

However, turning one's hobby into a job carries with it pitfalls as well as upsides (Dods, 2016; Stebbins, 2017a, 2017b). In many contemporary (post) industrial societies leisure came to be understood as 'not-work', the time that was left over from work and this defined the contours and parameters of people's relation to leisure (Budd, 2011; Komlosky, 2018; Korczynski et al., 2006; Roberts, 2013; Wright \& Wiersma, 2020). Devotee work, such as that of the professional bridge player, partially inverts this relation as it brings an activity that was experienced as leisure and morphs it into something understood as work (or paid labour to be more accurate). Consequently, many of the boundaries between work and leisure are rendered problematic, nebulous and potentially cast anew (Stebbins, 2017b). Leisure-as-work challenges well established conceptualisations of work and the identities of those who partake in it (Leidner, 2006). Thereby they offer compelling examples for a rethinking of relations between work and leisure and the porous boundaries that allow one to seep into the other. The move from turning a leisure activity, albeit a serious one, into paid work can be a complex one (Stebbins, 2017a, 2017b), particularly so when moving from being a serious amateur to becoming a 'Professional'. However, as suggested by Susskind and Susskind (2017, p.10), being a professional is as much about 'a labour of love and not simply labour for a wage' and fulfilled professionals can thus describe 'daily activities as a calling or vocation: not so much a job as a way of life'.

Exploring ideas of devotee work and the boundaries of work-leisure in the context of elite bridge brings to the fore the contested nature of bridge as a profession. Bridge, like other kinds of leisure, is increasingly a sphere with opportunities to earn a living, moving from amateur to professional (see Stebbins, 2017a). For many professional bridge players there is some ambivalence about whether they have a 'proper' job. The tensions involved in maintaining a passion and love for playing bridge while dealing with the ongoing realities of having to make a living whilst doing it, are central to ideas of devotee work. As bridge player, Tony, puts it, conceptualizing bridge as an actual job is quite difficult:

I suppose it's tradition as much as anything. In my younger days, it wasn't seen as being something that you ever made a living out of. It's difficult to 
come round to the conclusion that it now is a serious way of actually earning one's living. I think one element of the problem of earning your living through bridge, is how you have to do it. (Tony Forrester, England)

Hence, as explained above, the idea that bridge can be a 'profession' is a newer one, and one that invokes ideas of what it actually means to be a professional. As Susskind and Susskind (2017, p.11) discuss:

We want to trust professionals, to see them as upright people whose motives often seem noble, and for them to be embodiments of honesty, probity, and integrity. ...we imagine the professions are populated by people of good standing. ... The status and respect seem to incline many non-professional workers to want to be reclassified as belonging to the professions.

Hence, emphasis is placed here on the normative and ethical dimensions of being a professional and the nature of professions themselves. This invokes expectations of appropriate conduct from those calling themselves professionals and is tied into notions of the forms of recognition that can be secured through such work, with professional identity playing a large part in subjective life meaning (Dejours et al., 2018). The extent to which elite bridge, and players are 'professional' is complex and contested, as this bridge sponsor indicates:

It's not professional by and large. Not in this country. I think it's very professional in certain countries. I think it's something I feel is very, very wide. First of all, there's no professional body to monitor professionals so I actually find the use of a professional bridge player a bit of anathema. I can understand why we use that word but they're not professionals like dentists, accountants, doctors or architects. And so, when a paid bridge player doesn't perform as well as that person should, there's very little recourse. I tend to play with people who are, if you like, professional with a small p. They don't drink during tournaments, they always check all the frequencies and the scores to make sure, every time after the event, to make sure they got the right score. They go through a system several times before we play, they go through every board afterwards or as many as I want to. There are other players who just feel that the event is over. They can eat, disappear. That's not being a professional, so I think it's an unfortunate world. I think it's an unfortunate concept - professional bridge. Because bridge isn't really professional, it's paid bridge which I think is quite different. (Simon Gillis, England)

Moreover, a recent online discussion among bridge players showed players' concern with ethics (Legge, 2006) in relation to professionals:

[A]ll players (prof and non-prof) have the same responsibility to play by the rules. However, bridge professionals have by their position an additional responsibility to properly represent the game and set a high ethical example. (Bridge Winners social media platform) 
The idea of appropriate conduct refers not only to in-game behaviour and playing by the official rules, but extends outwards shaping players' identities and ideas about professionalism:

So that they have to dedicate time, time for people who are paying them, dress correctly - well dress is not very important - but just - if you went along to a lawyer who turned up stinking of whisky with a Hawaiian shirt, saying I went to bed at 3 last night, you'd be thinking, hang on a minute, why am I hiring you? (Simon Gillis, England)

Professional behavioural conduct also seeps into the extended leisure spaces (Scott \& Harmon, 2016) of tournament bridge, such as socializing before and after. Such spaces become a part of the work environment, where it is important to present oneself in the best light. As Adam Grossack (USA) reflects from the perspective of the professional, "when you are socialising with people are you really networking?' Overall given the growing numbers of players over the last four decades that have begun to earn a living from playing bridge, it is unsurprising to see concern with professionalism in bridge and the conduct of the professional player.

However, despite the importance placed on this among sponsors and professionals themselves, there remain wider perceptions that challenge the 'professional' nature of bridge and what it means to earn one's living from it in the context of ideas of work. Professionals are those who have been able to earn money from playing bridge, and there are no formalized structures, or bodies that dictate the terms for professional bridge players. Perceptions of bridge as a profession are mixed among amateur players. Some disagree with the concept of professional bridge and others point to the benefits of having bridge professionals, who can dedicate time to the game and improve the quality of bridge for everyone. The idea that bridge is not a proper job emerges from other elite players, and from the families of players:

Where I think bridge falls down as a profession is: let's take a scenario for example where I am playing with a client at a National. Now that to me is not a proper job. When I'm there, I'm prostituting my bridge playing ability. If you say prostitution is a proper job, then okay earning your money out of bridge is a proper job, but to me I don't think it is a proper job and therefore I don't think bridge is a proper job. (Tony Forrester, England)

My sister... is like, don't you want to do something that helps society? I'm like, I make a lot of money and spend it well, that helps the economy. I gave an economics point of view. She was not impressed. [...] I don't have any desire for greater good. If I am a good friend and a good boyfriend and a good person, I am helping society and that is good enough for me. I am doing what I love, and it makes me happy and that helps me to be not a shitty person. [...] I mean, it is your job, but it is a fun job. ... It's not like curing cancer, not like we were productive to society. (Justin Lall, USA) 
Negative perceptions of bridge as a form of work relate partly to its unusual working patterns and to the lack of respect associated with it being a card game. There is a sense, that some may consider players as undisciplined, wasting their intelligence, and not making a useful contribution to society. Often faced with the question of having committed their life to bridge, one professional remarked:

People used to say to me when I was a kid, 'Don't be a bridge bum.' But now they say, 'I was wrong. You did the right thing.' If your quality of life is good and you can play bridge all the time, then do that. If you can make money at it, it's good... Some of the best bridge players are the nicest guys. Do you think working in the financial world gives back? (Joe Grue, USA)

To contextualize bridge as a profession, it is worth highlighting that 45 years ago, Holz (1975) portrayed 'professional' duplicate bridge players as quasideviant hustlers working as secretly paid partners in a leisure activity that is officially held to be strictly amateur. The world of professional bridge has changed significantly since then, not that we are assuming that Holtz's characterization was strictly accurate or generalisable in the first place, but it is fair to say that the professional bridge player is tainted by associations with popular tales of 'card sharp' and in particular the shady world of 'underground poker' (Talberg, 2018; Vines \& Linders, 2016). Hence, there is an ongoing issue surrounding how bridge players can attain and maintain 'respectability', also discussed in poker (Hayano, 1977). Although, in dissonant fashion, it can be noted that bridge is possibly more likely to be understood as a somewhat staid but harmless parlour game played by older people in convivial surroundings.

The accounts of elite players above, are also mirrored in the experiences of Punch, in particular, the idea of convincing others to take bridge seriously within academia (Snellgrove, 2019). This parallels that of bridge professionals being told that what they do is not a proper job. As Punch pursued her leisure passion as an academic pursuit, there were challenges in convincing others of the merits of doing so, including in the domains of funding, publication and university research priorities. This was made more complex given the extent to which these areas had been separate previously, having built up a working career very separate to a leisure career. The challenges experienced were also felt by Punch as being possibly more pronounced than they might be with other sports and games, with bridge potentially questioned more so than chess for example, the value of which is more readily recognized as a serious endeavour in wider society and academia (Fine, 2015). The quantity of research on chess far outweighs that of bridge, and the question why bridge is often asked by journal reviewers extensively, suggesting a question mark over the validity of bridge as an area of academic study. 


\section{Earning a Living Doing Something you Love}

Of the 37 professionals in our research, only four mentioned earning a living as a reason why they play bridge. Instead, players talk about starting to play at a young age, having family members who play, and participating in bridge summer camps and school bridge lessons. The starting point for professional players is taking up bridge as a leisure pursuit and falling in love with the game (Punch et al., 2021). Over time, there is then a journey from leisure to work and the lifestyle of a professional bridge player, is considered markedly different from other kinds of work:

Basically, work is three tournaments a year and I don't have to go to the office every day. I have a lot of freedom, whereas most people get up, go to the office, go home, have good... and then go to sleep. I don't live that schedule. I get up at eleven o' clock in the morning and I stay up at night, so I don't live the standard life. (Marion Michielson, The Netherlands)

Hence for professional players the blurring of leisure into work has allowed them to reject the 9-5 work routine and also invites opportunities to travel the world as part of the job:

Depends what your priorities are in life. I am sure my skill set would have translated very well to trading and the like, but I would have hated working 8-6 or whatever the modern standard is. Instead, I have a flexible schedule, a big overlap between my work and my hobby/passion, and I get to travel the world. (Mike Bell, England)

I always dreamed of going to certain places and with the bridge I know travel has become a lot more affordable... I probably wouldn't have gone to half of these places. (Jason Hackett, England)

Given travel can be itself a form of leisure, it is easy to see why professional bridge players could be devoted to the lifestyle of being a professional player. There is a chance to see new places and connect with others passionate about bridge in the extended leisure experiences of the social world of tournament bridge. For example, they engage in 'post-mortems' (Scott \& Harmon, 2016) where players discuss the happenings of the match afterwards, usually in a social setting such as a restaurant or hotel bar. Overall, players felt that despite it being their job, they would still play bridge regardless of being paid:

...now I play bridge for other reasons, it's how I make money and also, I mean

I would have it as a hobby if I didn't have it as a job. (Jenny Wolpert, USA)

This commitment indicates the characteristics of devotee work as described above and is strongly reflected in the positive experiences of players. For example, players referred to being able to 'earn a living doing something I love' (Jill Levin, USA) and 'bridge itself is a fascinating game and making a living out of something you are really passionate about is great' (Nevena Senior, England). It is regarded as a privilege to make money doing something you enjoy (Anthony 1991), and there is the potential to earn respect from peers. Unlike many careers, 
being a bridge professional does not need a licence or an interview in order to earn a living, but it does require that the individual has moved up the rankings by winning competitions. Being a bridge professional can therefore bring players a feeling of status (Leidner, 2006) within this specific community. This is something players enjoy compared to other forms of work:

I enjoy the kind of adulation that I get from being a bridge pro, whereas in a firm where I was an accountant there was nothing special about me - often not treated particularly well, whereas here I am treated a bit like a hero. (Heather Dhondy, England)

The competition element of bridge with a clear winning and losing element, contributes to the possibility of receiving such adulation. Even if one does not win the match, playing well would be a cause to receive praise from other players and observers. This corresponds to the wider reflection that leisure is 'a site where individuals seek to display their status and distance themselves from individuals and groups deemed undesirable [within the context of] standards of emulation in many leisure social worlds that inspire participants to collect experiences' (Scott, 2017 , p.397). In terms of work, the idea that players also have time to indulge in their passion and hone their skills could be considered in relation to the idea of 'craft' work (Sennet, 2008). 'Craftsmanship' emphasizes the ethics of doing a job well for its own sake and this crucially involves a sensuous interweaving of the body and mind in the completion or carrying out of a task. As part of this process, one then may be able to achieve a state of 'flow' (Csikszentmihalyi, 1998). Sennet (2008, p.9) in a reworking of Arendt's distinction between 'work' and 'labour', describes 'craftsmanship' as relating to a basic human impulse of wanting to do a job well:

Craftsmanship focuses on objective standards, on the thing itself ... it focuses on the intimate connection between hand and head. Every good craftsman conducts a dialogue between concrete practices and thinking: this dialogue evolves into sustaining habits, and these habits establish a rhythm between problem solving and problem finding (see also Mills, 1951, on earlier discussion of idealised notions of 'craft').

For professional bridge players, unlike amateurs, they can hone their craft, or more specifically their skills at the bridge table given the amount of time they have engaged in the practices and habitual playing:

If every day you are playing 48/50/60 hands of bridge a day, then it's all, it's just much more like breathing. [...] Whereas if you're not a very strong player or if you're not used to playing that amount any more, you have to think more. Yeah it, it doesn't come as naturally and so I think the kind of concept to having been bridge fit actually works as well. If that's your job it's easier. You know, somebody who is only an academic at weekends, they're gonna find it hell of a lot harder than somebody who's an academic Monday to Friday, and that's their job. (Alan Mould, England) 
The time investment allows players to reach the top of the game, to hone their craft as a player (see also Punch, 2021). Bridge is a partnership game however, meaning that this process is always done in relation to an 'other', one's partner, situating craftsmanship firmly within the realm of social interaction. This invokes Fine's (2015) discussion of flow in chess, which is rooted social relations and can only be achieved at particular moments and is shaped by the skill level of players in the game. Thus, whilst establishing individual skills, players also develop in partnership to become 'in tune' with each other and establishing long-term social bonds and communication is key to success (Punch et al., 2020). Considering the above, bridge offers the possibility for 'meaningful work' which includes both the possibility for individual fulfilment and has an orientation towards others (Patulny, 2020).

Professionals have long been known for the special orientation they hold towards their work (Susskind \& Susskind, 2017). This orientation, which may be shared by the majority of members of a given profession, reaches its broadest expression in a common outlook referred to here as the spirit of professional work (Stebbins 2000). This concept denotes the distinctive set of shared values, attitudes and expectations that form around a given type of professional work. As a result of their occupational socialization, the work itself is seen by its practitioners as socially important, highly challenging, intensely absorbing, and for these reasons among others, immensely appealing. This work is exceedingly complex, executed most effectively by practitioners with many years of training and experience and involve high levels of 'craft' (Sennet, 2008). Additionally, the spirit of professional work pervades the work lives of a sufficient number of employed professionals to constitute an important part of their occupational subculture. Thus, from what is known through research on occupations in general, this spirit, as expressed in each profession, endows the culture of that profession with a special quality not found in any other profession or, more broadly, any other occupation (Dejours et al., 2018). However, bridge is yet to be fully professionalized, and the contested nature of the spirit of the profession is evident from our findings in this paper.

The experiences of players again can be mirrored in the experience of Punch and the ways in which this has allowed her to legitimately integrate her leisure into work. This brings many benefits such as a renewed passion for research and goes beyond the 'blurry boundary between labour and leisure... the familiar professional haunt, if not the home, of every academic' (Carton, 2008, p.375). For example, as well as attending tournaments whilst on annual leave, tournaments become part of the working identity of being a sociologist, and in turn the sociologist becomes part of the identity of being a bridge player as the two social worlds merge to create a liminal space that blends labour and leisure (Carton, 2008). Thus, the extended leisure experiences as described by Scott and Harmon (2016) become sites where work and play intersect at bridge tournaments. Furthermore, within this liminal space, when writing up bridge projects in the office Punch engages in 'playful work' and can experience flow through being adequately challenged, intensely concentrating and engrossed to the point of losing track of time (Muirhead, 2004). However, experiencing bridge as a liminal space blending work and play is not without its personal and structural challenges for both the researcher and the bridge professionals. 


\section{It's Difficult when your Hobby Becomes your Work}

Such a transitioning over boundaries points to the liminality of the work of the devotee bridge player. Liminality as developed within anthropology (Turner, 1974; Van Gennep, 1960) emphasizes the potential for ambiguity and disorientation that may result as a consequence of being at a threshold and then moving into another state. Liminal periods can be uncertain and what was previously taken for granted, as well as future outcomes, can be cast into some doubt (Sethie, 2019; Turner, 1974). The double-edged sword of crossing the boundary from leisure to work, emerged in our findings through some of the more negative perceptions from players. Overwhelmingly ideas of serious leisure and devotee work are conceptualized as positive for participants (Stebbins 2009, 2020), however in contrast, players said:

Now, I play bridge because it's my living and it's fair to say that because of the type of partner I get playing professionally, a certain amount of the enjoyment of the game has been gradually knocked out of me. (Brian Senior, England) I feel bridged out... it's difficult when something that's your hobby becomes your work as well. (Simon Cope, England)

These feelings could be explained in terms of what makes an activity more play-like or work-like (Bell, 2009). Intrinsic rewards of activities are the enjoyment and personal satisfaction received, whereas extrinsic rewards include financial gain. Extrinsic rewards make the activity become less about enjoyment and more about work (Butcher and Schneider 2007; Weeks, 2011). Brian's statement indicates that bridge for him, as a professional player, can be more work-like and has lost some of its intrinsic motivations. Becker (1963) long ago noted the tension between US club musician's identities of being a jazz musician (playing what they want) and a commercial musician (playing what the customer wants) (Budd, 2011). Becker's jazz musicians only self-identified as being 'proper' jazz musicians when they were able to play what they wanted, everything else being experienced as a compromise. A similar process is evident with professional bridge players. Stebbins (2017a, p.15) notes that dissatisfaction and disassociation within devotee work is linked to the distance the individual 'devotee' is from the 'core tasks' of the activity:

The devotees must work in a physical and social milieu that encourages them to pursue often and without significant constraint the core activities. This includes avoidance of excessive paperwork, caseloads, class sizes, market demands and the like.

Devotee professional bridge players often note the various obstacles that appear in the course of their work that routinely limit their closeness to the core activities of bridge, which are the key source of self-identity and attunement as an elite professional player. As the following respondents note:

I don't like the politics, I don't like that you have to be hired... it's not just how well you play, you have to get hired, and schmooze and go out to dinner. There is that part where sometimes you just don't want to go out to dinner or to the bar, be politically correct. (Justin Lall, USA) 
So, it's not something I would like to do because I've done it and playing day after day in club duplicates... for me it's a bit soul destroying and actually you lose some of your love for the game if you do that every day. (Jason Hackett, England)

Jason considers himself lucky that he has sufficient paid bridge work at tournaments that he does not need to play regular club bridge every week with a client (the 'club duplicate') where the standard tends to be lower. Thus, the experience of working at play can generate negative experiences for professional players including the insecurity and precarious nature of employment in a professionalizing activity in uneven ways that rarely offer formalized work. For example, sick pay and health insurance for US players is a prominent issue (Standing, 2011).

Professional players are also dependent on their results which are directly linked to their opportunities for paid employment in bridge, and there is a significant amount of pressure associated with this situation. This might also involve the deployment of social skills to ensure clients favour them as a choice for paying to play with. As Justin indicates above, socializing with clients after the game and discussing the bridge hands is frequently an expected part of the package. In a forthcoming paper (Punch \& Russell, 2021) analyse the emotion management engaged in by elite bridge players. Professionals, more so than amateurs, appear to feel pressure to manage and suppress emotions (Bolton, 2004; Wolkowitz, 2006) in order to obtain and retain their position being paid to play bridge. There is also the wider relationship between the professional and the client that must be managed. Clients must gain what they want from the relationship, including learning and teaching and ultimately success out of the partnership. Professional players must therefore manage relationships and emotions:

You have to just be super nice to them all the time... you'd have to tiptoe really carefully about whether you can or can't even mention their errors... some clients who just want to win and so you just have to be caressing their ego. (Anonymous)

This again puts players into a position of having to be more strategic and less free in their play by having to concern themselves with strategies to ensure the necessary results, which can produce negative effects: 'I find it very stressful because I feel you've got to produce results' (Liz McGowan, Scotland). Whilst all bridge partnerships engage in this to a certain extent, the client-pro relationship, and the situation of players whose primary income depends on their performance is more intense and stressful. For example, when it comes to failures, players may then be tempted to avoid taking blame or admitting their own errors in front of the client:

[I]f you're making your living out of it, there's even more pressure to present your partnership in a good light. If you've lost a match it wasn't down to you and partner, it was down to the other pair. (John Matheson, Scotland)

Hence some players would rather pursue a more structured work life that provides security and routine, regardless of performance: 
...working in a school is very structured and that suits me very well, whereas bridge work is complete opposite. It is irregular... I like the security of knowing this is where I get paid every month, regardless of how many crap days I have. (Sarah Bell, England)

Finally, just as travel can be perceived as one of the benefits of playing bridge professionally it can also be considered as a negative part of the job. With significant amounts of travel professional players are away from home for long periods at a time:

I'm sort of afraid of living out of a hotel for 50 weeks. I do like cooking my own food, staying at home, chilling on the couch but I don't know how all these bridge players play week after week after week... I don't want to be homeless. (Anam Tebha, USA)

This kind of negative perception of the lifestyle of a bridge professional is also part of the more exclusionary aspects of professional bridge. For example, those with caring responsibilities are less likely to be able to take up bridge as full-time, travelling professionals, compared with single individuals with no other life commitments to consider. Thus, as one player describes, 'the negatives are the weird lifestyle if you're trying to raise children and have a family and a healthy marriage' (Adam Grossack, USA). As has been argued elsewhere, these dynamics will disproportionately affect women (Ferguson, 2020; Gottfried, 2006; Hochschild, 2003; Weeks, 2011). In players' descriptions:

[Y]ou have a lot more professional men than women and it is all related to what women have to do. Like you have a family you will really struggle to cope with childcare, job, playing bridge. (Nevena Senior, England)

If it's a job it's alright to go away for a couple of weeks but if it's for fun then it kind of isn't. (Sally Brock, England)

Hence the possibilities for blurring the boundaries between work and leisure are distinctly gendered. Opportunities to pursue bridge as a form of devotee work hinge on the ability to commit to participation in an international leisure pursuit and associated stresses and pressures to succeed in an unstructured, precarious working environment that would dictate one's entire way of living to the possible detriment of other areas of one's life. Punch et al. (2021) highlight the position of bridge in players' lives, showing devotees in paid employment position bridge as more central in their lives than those that have other jobs and commitments, pursuing bridge only as a form of leisure.

The experiences of Punch relating to the above themes, include the sense in which blurring the lines between work and leisure by researching bridge can leave one feeling 'bridged out' with little time off for non-bridge activities. Additionally, similar to the ways professionals talk about clients and impression management, Punch is increasingly conscious about enacting a bridge identity because of the association with the professional work as a sociologist. Whilst previously she would be free to comment on bridge matters and behave in certain ways as a player, she must now consider the impacts on the research and the relationships which 
have been developed over time with bridge organizations. This is particularly acute where bridge audiences are contributing funding and closely invested in the research (Punch \& Rogers, 2021). Finally, blurring the lines between work and leisure is feasible without children and with a bridge playing partner. A non-bridge partner might not be so understanding of the extra time commitment involved and being absorbed by bridge, including time away from home now for bridge research as well as bridge playing.

\section{Blurring the Boundaries between Leisure and Work}

One of the clear findings around the blurred boundaries between work and leisure in elite bridge, is that these unfold in varied and diverse ways for players. Professional players can move between positive and negative experiences, dependent on: the playing context (specific relationships with a paid client and the kind of bridge one plays), wider circumstances as a player (whether there are sustained opportunities for income), and the associated pressures of seeking income from bridge. Bridge is professionalizing in an uneven manner geographically with opportunities for professional work clustered in the likes of London and New York. Opportunities are also more limited for those who cannot tailor their lifestyle to the needs of being a travelling bridge professional, such as those with family commitments. Despite this, there are few other settings in which the lines between leisure and work are so blurred in terms of the amateur/professional constitution of the elite playing community, with some adhering to ideas of professionalism and others engaging in an activity that is purely a hobby.

The elite community of high-level tournament bridge players is arguably a liminal space, where devotee work is possible, but does not characterize the experiences of all involved. Some players for example choose to maintain harder boundaries between work and leisure, whilst others are devotees to the game and thrive on the lifestyle that being a professional entails. The range of work-leisure experiences should perhaps be seen on a continuum, ranging from those that are thrilled to be on a 'permanent holiday' (Mike Bell, England) and to be playing at work, to those that are working at play and experience the negative side of one's leisure becoming one's work. The latter include those who would never wish to see their hobby become their job:

I would never just commit my whole life to bridge. I find that really bizarre that people, I mean, it's not a game then, it's your job. (Yvonne Wiseman, Scotland)

$[\mathrm{M}] \mathrm{y}$ psychology to do with the game is not to associate the game with money. It's been a hobby, as long as it remains a hobby I enjoy doing that's great, but it's not a profession. I think something happens to you when something moves from being a hobby to a profession. (Tony Forrester, England)

For these players, the enjoyment derived from leisure and play is part of a mindset about bridge and notions of what constitutes work. Thus, if bridge became a form of paid labour, this changes a player's relationship to the game. Some players conveyed 
the idea that the economic exchange of labour for services, taints ones' relationship to bridge and can be 'soul destroying' to undertake daily. Despite the positive feelings from those paid to play, others referring to the work as 'prostituting' one's ability, seems to invoke the idea of bridge as a problematic form of work, in stark contrast to ideas of devotee work. The preference here is a matter of choice in terms of shaping one's relationship to the game and the kinds of activities that this involves dedicating time to:

[W] hen it was my hobby I loved it much more. It's about choice, you do when you want. When it's a job it's a job, always keep a hobby. When it was a hobby, it was a much more attractive thing. I achieve much more since I became professional, I saw much more big bridge, I play much better bridge. It all gives, professional gives, more time for bridge, focus more. But it's less fun. You end up places you wouldn't go, to play. (Artur Malinowski, England)

In theory, blurring the boundaries between work and leisure, might take the pressure off from having to struggle to find work-life balance between one's passion and one's paid employment (Budd, 2011; Shell, 2018; Weeks, 2011). On the other hand, the blurred boundaries between work and leisure may make finding a balance even harder and decrease overall life satisfaction. Dewey (1916) argued that there is no pure play, and no pure work, and further that intellectual harm arises from divorcing the two (Breunig, 2017). He thought that to be playful and serious at the same time was wholly possible and considered this an ideal mental condition (Breunig, 2017). There is clearly some scope for this in terms of the experiences of those bridge professionals that align best with notions of devotee work.

Given the barriers to participation in elite level bridge as a form of leisure (for those who are not paid professionals) and the possible negative aspects of devoting oneself to their hobby as a form of paid labour, it is arguably beneficial to conceptualize bridge through the lens of liminality capturing the blurred boundaries between work and leisure. However, this situation is likely to continue to produce mixed perceptions of bridge as a profession with the comparative perspectives of respect and derision for those who earn a living playing cards. Davis (1984, p.234) in his discussion of Hughes' classic account of 'dirty work' (1962) argues that, 'stigmatized occupations attract certain kinds of individuals who, because of their psychological or social characteristics contribute to the occupation's reputation'. It is evident that some of this 'stigma' (Goffman, 1963) continues to besmirch, to some extent, the professional bridge player particularly in their understandings and projections of themselves as being a 'professional' and having a 'proper' occupation (Harper, 2007).

A focus on the world of the professional bridge player draws out a range of interesting aspects of the move from [serious] leisure into potential/forms of "professionalism', the relations between work and leisure and the formation of work-related identities. In terms of scales of involvement, devotee work is at the opposite end of the continuum from casual leisure and the 'dabbler' in a pursuit and goes beyond serious leisure into a new space (Stebbins, 2017a). Discussing professionals and amateurs in serious leisure, Stebbins (2017a) suggests that whilst professionals were first amateurs, many amateurs never consider, and indeed reject, the possibility of 
making a living from their pursuit. This is also clear in the elite bridge player community, where some prefer to maintain a separation of work and leisure and find the idea of blurring the boundaries unappealing.

For those that do undertake the transition from leisure through to paid work this process is fraught with specific structural and cultural contingencies (ibid). These include the geographically uneven distribution of opportunities for paid work, the need to nurture and sustain client relationships, and expectations around working life and travel that are challenging for those with caring commitments and families. That being said, the maintenance stage of careers in client-oriented professions is potentially 'the greatest expression of skill, knowledge, and experience combined with the highest level of remuneration' (Stebbins, 2017a, p.138). For professionals in bridge, this is a possibility, but not a guarantee, because their performance of skill is ultimately tied up in their partnership and playing with a client could mean playing at a lower level of skill than one might be able to otherwise. This adds a new layer to navigating the challenges of establishing a career as a professional and the question of how to maintain a level of devotee work that finds a balance between an all-consuming quantity that leads to a dispiriting experience and a lack of work which threatens the livelihood (ibid). Not all bridge matches, partnerships and activities are created equal. As a professional player, one may have to engage in types of work that take one further away from the ideal and what it is about bridge that inspired devotion, and closer towards a form of paid labour that is less enjoyable but essential to livelihood.

\section{Conclusion}

This paper contributes to discussions of devotee work and the blurring of boundaries between work and leisure. Bridge at elite level invokes a sense of liminality, being neither fully professionalized, nor fully experienced as leisure. The idea of bridge as a profession is contested, both by players themselves and wider societal perceptions of bridge and the nature of work itself. On the one hand, there are no formalized professional bodies to shape work ethics and expectations. Yet, on the other hand, there is evidence of a spirit of professional work linked to status and respect, conduct and identity. Those who are paid to play are engaged in devotee work in a contextually specific enactment of a professional identity, which involves reflecting on how one is perceived and what constitutes being a bridge professional. The lived experiences of professional bridge may speak to other mind-sports or mind-games, such as chess or poker. Many of the dynamics for players mirror the research process itself which originated through devotee work of Punch who integrated bridge as leisure with academic work as a sociologist. Research about bridge and the lifestyle of a professional player are both questioned in relation to the moral worth of making a living or focusing one's academic attention on a card game.

This paper has shown that engaging in devotee work ultimately produces new liminal spaces in which one can experience both positive and negative effects of the blurring of boundaries between work and play. The upsides include the potential for achieving flow, playful seriousness and the joy of being paid to do something 
you love. The downsides refer to uneven opportunities and structural barriers for some players to participate in devotee work, alongside how turning play into work can take the joy out of the activity. Thus, the paper presents a more nuanced picture of occupational devotion in the context of a leisure activity, which has previously been referred to as 'ideal' (Stebbins, 2020, p. 25). We have argued that liminality describes a process and an experience of transitioning across blurred boundaries and this fits well with devotee work of the elite bridge player. The liminality of elite level bridge is evident in how we can understand devotee work which reflects the above tensions and complexity. Hence, devotee work can occupy a transitional space which simultaneously encompasses both positive and negative experiences. There is a blurring of boundaries between leisure and work for professional players, whilst at the same time other elite players continue to maintain harder boundaries between paid work and bridge as leisure.

Acknowledgements We are very grateful to all the research participants for sharing their experiences and views of professional bridge. We thank Bridge: A MindSport for All for contributing to the funding to enable this research to be completed (see bridgemindsport.org). We would also like to thank Elizabeth Graham, Catriona Galbraith, Jenny Galbraith and Kevin Judge for their early inputs to this paper including sorting and coding some of the data.

Open Access This article is licensed under a Creative Commons Attribution 4.0 International License, which permits use, sharing, adaptation, distribution and reproduction in any medium or format, as long as you give appropriate credit to the original author(s) and the source, provide a link to the Creative Commons licence, and indicate if changes were made. The images or other third party material in this article are included in the article's Creative Commons licence, unless indicated otherwise in a credit line to the material. If material is not included in the article's Creative Commons licence and your intended use is not permitted by statutory regulation or exceeds the permitted use, you will need to obtain permission directly from the copyright holder. To view a copy of this licence, visit http://creativecommons.org/licen ses/by/4.0/.

\section{References}

Applebaum, H. (1992). The concept of work: Ancient, medieval and modern. State University of New York Press.

Arendt, H. (1958). The human condition. Chicago University Press.

Becker, H. S. (1963). Outsiders: Studies in the sociology of deviance. Free Press.

Bell, B. (2009). Sports studies. Learning Matters.

Bolton, S. C. (2004). Emotion management in the workplace. Red Globe Press.

Brannick, T., \& Coghlan, D. (2007). In defense of being "native": The case for insider academic research. Organizational Research Methods, 10(1), 59-74.

Braun, V., \& Clarke, V. (2006). Using thematic analysis in psychology. Qualitative Research in Psychology, 3(2), 77-101.

Breunig, M. (2017). John Dewey: Purposeful play as leisure. In K. Spracklen, B. Lashua, E. Sharpe, \& S. Swain (Eds.), The Palgrave handbook of leisure theory (pp. 355-370). Palgrave Macmillan.

Budd, J. W. (2011). The thought of work. Cornell University Press.

Carton, E. (2008). Labour, leisure and liminality: Disciplinary work at play. Leisure Studies, 27(4), $375-378$.

Csikszentmihalyi, M. (1998). Finding flow: The psychology of engagement with everyday life. Basic Books.

Davis, D. S. (1984). Good people doing dirty work: A study of social isolation. Symbolic Interaction, $7(2), 233-247$. 
Dejours, C., Deranty, J.-P., Renault, E., \& Smith, N. H. (2018). The return of work in critical theory: Self, society, politics. Columbia University Press.

Dewey, J. ([1916] 2013). Democracy and education: An introduction to the philosophy of education. Read Books Ltd.

Dods, R. (2016). Is turning a hobby into a career ever a good idea? The Guardian, available: https://www. theguardian.com/small-business-network/2016/jun/14/is-turning-hobby-into-career-ever-good-idea

Ferguson, S. (2020). Women and work: Feminism, labour and social reproduction. Pluto Press.

Fine, G. (2015). Players and pawns: How chess builds community and culture. University of Chicago Press.

Fleming, J. (2018). Recognizing and resolving the challenges of being an insider researcher in work- integrated learning. International Journal of Work-Integrated Learning, 19(3), 311-320.

Goffman, E. (1963). Stigma: Notes on the management of a spoiled identity. Simon \& Schuster.

Goffman, E. (1990). The presentation of self in everyday life. Penguin.

Gottfried, H. (2006). Feminist theories of work. In M. Korczynski, R. Hodson, \& P. Edwards (Eds.), Social theory at work (pp. 121-154). Oxford University Press.

Harper, D. (2007). Work and occupations. In C. D. Bryant \& D. L. Peck (Eds.), 21 st century sociology: A reference handbook (pp. 218-227). Sage.

Hayano, D. M. (1977). The professional poker player: Career identification and the problem of respectability. Social Problems, 24(5), 556-564.

Hochschild, A. R. (2003). The second shift. Penguin.

Holz, J. A. (1975). The 'professional' duplicate bridge player. Urban Life, 4, 131-148.

Hughes, E. C. (1962). Good people and dirty work. Social Problems, 10(1), 3-11.

Hughes, E. C. (1971). The sociological eye: Selected papers. Aldine Atherton.

Komlosky, A. (2018). Work: The last 1000 years. Verso.

Korczynski, M., Hodson, R., \& Edwards, P. (Eds.). (2006). Social theory at work. Oxford University Press.

Legge, K. (2006). Ethics and work. In I. M. Korczynski, R. Hodson, \& P. Edwards (Eds.), Social theory at work (pp. 299-324). Oxford University Press.

Leidner, R. (2006). Identity and work. In M. Korczynski, R. Hodson, \& P. Edwards (Eds.), Social theory at work (pp. 424-463). Oxford University Press.

McIntosh, I., \& Wright, S. (2019). Exploring what the notion of 'lived experience' might offer for social policy analysis. Journal of Social Policy, 48(3), 449-467.

Mercer, J. (2007). The challenges of insider research in educational institutions: Wielding a doubleedged sword and resolving delicate dilemmas. Oxford Review of Education, 33(1), 1-17. https://doi. org/10.1080/03054980601094651

Mills, C. W. (1951). The American middle classes. Oxford University Press.

Muirhead, R. (2004). Just work. Harvard University Press.

Patulny, R. (2020). The emotional trade-off between meaningful and precarious work in new economies. Journal of Sociology, 56(3), 333-355.

Punch, S. (2021). Bridge at the Top: Behind the Screens. Toronto: Master Point Press.

Punch, S., \& Rogers, A. (2021). Building, not burning bridges in research: insider/outsider dilemmas and engaging with the bridge community. Journal of Leisure Research. https://doi.org/10.1080/00222 216.2021.1887782

Punch, S., \& Russell, Z. (2021). Playing with emotions: emotional complexity in the social world of elite tournament bridge. Bridge: A MindSport for All international conference: bridging academia, policy and practice, 28 June-1 July 2021. Available: https://bridgemindsport.org/bridging-academiapolicy-practice-conference/conference-2021-day-1/

Punch, S., Russell, Z., \& Cairns, B. (2020). (Per)forming identity in the mind-sport bridge: Self, partnership and community. International Review for the Sociology of Sport, 56(6), 804-822. https://doi. org/10.1177/1012690220959648

Punch, S., Russell, Z., \& Graham, E. (2021). Serious leisure experience in a dyadic pursuit: elite player motivations and participation in tournament bridge. Leisure Studies. https://doi.org/10.1080/02614 367.2021.1942524

Roberts, K. (2013). Sociology of leisure. Sociopedia.isa. https://doi.org/10.1177/205684601371

Schutz, A. ([1932] 1967). The phenomenology of the social world. Northwestern University Press.

Scott, D. (2017). Why Veblen matters: The role of status seeking in contemporary leisure. In K. Spracklen, B. Lashua, E. Sharpe, \& S. Swain (Eds.), The Palgrave handbook of leisure theory (pp. 385400). Palgrave Macmillan. 
Scott, D., \& Harmon, J. (2016). Extended leisure experiences: A sociological conceptualization. Leisure Sciences: An Interdisciplinary Journal, 38(5), 482-488.

Sennet, R. (2008). The craftsman. Penguin Books.

Sethie, N. (2019). Regulating for uncertainty: Bridging blurred boundaries in medical innovation, research and treatment. Law, Innovation and Technology, 11(1). https://doi.org/10.1080/17579961. 2019.1573400

Shell, E. R. (2018). The job: Work and its future in a time of radical change. Currency.

Snellgrove, M. L. (2019). Taking bridge seriously. Discover Society. Available: https://discoversociety. org/2019/12/04/takingbridge-seriously/

Sohn, E. (2018). How to turn your interests into a career. Nature. Available: https://www.nature.com/artic les/d41586-018-07357-2

Standing, G. (2011). The precariat: The new dangerous class. Bloomsbury.

Stebbins, R. A. (2004). Erasing the line between work and leisure in North America. Paper presented at the "Leisure and Liberty in North America" Conference held 12-13 November 2004, University of Paris IV, Paris, France.

Stebbins, R. A. (2017a). Careers in serious leisure: From dabbler to devotee in search of fulfilment. Palgrave Macmillan.

Stebbins, R. A. (2017b). Devotee work as leisure. In Leisure's legacy: Leisure studies in a global era (pp. 155-170). Palgrave Macmillan.

Stebbins, R. A. (2020). The serious leisure perspective. Palgrave Macmillan.

Strangleman, T., \& Warren, T. (2008). Work and society: Sociological approaches, themes and methods. Routledge.

Susskind, R., \& Susskind, D. (2017). The future of professions: How technology will transform the work of human experts. Oxford University Press.

Talberg, N. (2018). Don't talk to them, they will not understand: How poker players experience criticism and stigma. Journal of Gambling Issues, 39, 258-291.

Turner, V. (1974). Liminal to liminoid, in play, flow, and ritual: An essay in comparative symbology. Rice University Studies, 60(3), 53-92.

Vaismoradi, M. and Snelgrove, S. (2019). Theme in qualitative content analysis and thematic analysis. Forum Qualitative Social Research, 20(3). Available at: https://www.qualitative-research.net/index. php/fqs/article/view/3376/4470

Vaismoradi, M., Jones, J., Turunen, H., \& Snelgrove, S. (2016). Theme development in qualitative content and thematic analysis. Journal of Nursing Education and Practice, 6(5), 100-110.

Van Gennep, A. (1960). The rites of passage. Routledge \& Kegan Paul.

Veblen, T. ([1899] 1963). Theory of the leisure class. New English Library.

Vines, M., \& Linders, A. (2016). The dirty work of poker: Impression management and identity. Deviant Behavior, 37(9), 1-13.

Weeks, K. (2011). The problem with work: Feminism, marxism, antiwork politics and postwork imaginaries. Duke University Press.

Wolkowitz, C. (2006). Bodies at work. Sage.

Wright, R. K., \& Wiersma, C. (2020). "It pays to play": The emergence of innovative planning, occupational devotion and lifestyle entrepreneurship in Aotearoa/New Zealand. In V. Ratten (Ed.), Sport entrepreneurship and public policy: Building a new approach to policy (pp. 22-39). Springer Press.

Publisher's Note Springer Nature remains neutral with regard to jurisdictional claims in published maps and institutional affiliations. 